Institute and Faculty of Actuaries

ISSN 1357-3217

\title{
British Actuarial Journal
}

VOLUME 21 - PART 3

Current practitioner research and discussion in actuarial science 


\title{
Institute and Faculty of Actuaries
}

\author{
Staple Inn Hall \\ 7 Conference Square \\ Edinburgh - EH3 8RA \\ Holborn Gate \\ 4 Worcester Street \\ High Holborn \\ Oxford - OX1 2AW \\ London - WC1V 7PP
}

$\begin{array}{ll}\text { Managing Editor: } & \text { Cathy Robertson } \\ \text { Co-Editors } & \text { Trevor Couper } \\ & \text { Rose Walkling } \\ \text { Assistant Editors: } & \text { Sanjeev Bhalla } \\ & \text { Wendy Crockford } \\ & \text { Jonathan Finn } \\ & \text { Robert Hudson }\end{array}$

\section{Subscriptions}

British Actuarial Journal is published three times a year by Cambridge University Press for the Institute and Faculty of Actuaries. The 2016 subscription price is $£ 153$ (US\$261) for print and electronic access. The electronic-only rate is $£ 129$ (US\$222).

Cambridge University Press also publishes Annals of Actuarial Science for the Institute and Faculty of Actuaries. A bundled subscription to both journals is available at $£ 233$ (US\$405) for print and electronic access. The electronic-only rate is $£ 199$ (US\$346). Annals of Actuarial Science is also available as a standalone subscription at the same prices as the British Actuarial Journal above. All prices include delivery by air if appropriate, and exclude VAT. EU subscribers (outside the UK) who are not registered for VAT should add VAT at their country's rate. VAT registered members should provide their VAT registration number. Japanese prices for institutions (including ASP delivery) are available from Kinokuniya Company Ltd, P.O. Box 55, Chitose, Tokyo 156, Japan.

Orders, which must be accompanied by payment, may be sent to a bookseller, subscription agent or direct to the publisher: Cambridge University Press, Journals Fulfilment Department, UPH, Shaftesbury Road, Cambridge CB2 8BS, UK, email journals@cambridge.org or in the USA, Canada and Mexico: Cambridge University Press, Journals Fulfillment Department, 1 Liberty Plaza, Floor 20, New York, NY 10006, USA, email subscriptions_newyork@cambridge.org. Copies of the Journal for subscribers in the USA, Canada and Mexico are sent by air to New York to arrive with minimum delay. Postmaster: send address changes in USA, Canada and Mexico to Africa, Journals Fulfillment Department, 100 Brook Hill Drive, West Nyack, New York 10994-2133; or e-mail subscriptions_newyork@cambridge.org. Claims for missing issues will only be considered if made immediately on receipt of the subsequent issue.

\section{Copying}

All rights reserved. No part of this publication may be reproduced in any form or by any means, photocopying, electronic, or otherwise, without permission in writing from Cambridge University Press. Permission inquiries from the USA, Mexico, and Canada should be addressed to the New York office of Cambridge University Press http:// www.cambridge.org/us/information/rights/contacts/newyork.htm; permission inquiries from elsewhere should be addressed to the Cambridge office http://www. cambridge.org/uk/information/rights/contacts/cambridge.htm; permission inquiries from Australia and New Zealand should be addressed to the Melbourne office http://www. cambridge.org/aus/information/contacts_melbourne.htm. Permission to copy (for users in the USA) is available from the Copyright Clearance Center (CCC), http://www.copyright.com, email: info@copyright.com. Specific written permission must be obtained for republication; contact the nearest Cambridge University Press office.

\section{Advertising}

To advertise in the journal please contact the relevant Advertising Promoter for your area: in the USA, Canada or Mexico: journals_advertising@cup.org or telephone +1 (212) 337 5053; in the UK, Europe or rest of the world: ad_sales@cambridge.org or telephone +44 (1223) 325083. 